Article

\title{
A Cellulosic Fruit Derived from Nerium oleander Biomaterial: Chemical Characterization and Its Valuable Use in the Biosorption of Methylene Blue in a Batch Mode
}

\author{
Youssef O. Al-Ghamdi ${ }^{1}$, Mahjoub Jabli ${ }^{1}{ }^{1} *$ D, Raoudha Soury ${ }^{2}$ and Shahid Ali Khan ${ }^{3}$ \\ 1 Department of Chemistry, College of Science Al-Zulfi, Majmaah University, \\ Al-Majmaah 11952, Saudi Arabia; yo.alghamdi@mu.edu.sa \\ 2 Chemistry Department, Faculty of Science of Hail, University of Hail, Hail 81451, Saudi Arabia; \\ ra.soury@uoh.edu.sa \\ 3 Department of Chemistry, University of Swabi, Swabi Anbar, Khyber Pakhtunkhwa 23561, Pakistan; \\ skhan@uoswabi.edu.pk \\ * Correspondence: m.jabli@mu.edu.sa
}

Received: 9 October 2020; Accepted: 26 October 2020; Published: 30 October 2020

\begin{abstract}
Cellulose substrate waste has demonstrated great potential as a biosorbent of pollutants from contaminated water. In this study, Nerium oleander fruit, an agricultural waste biomaterial, was used for the biosorption of methylene blue from synthetic solution. Fourier-transform infrared (FTIR) spectroscopy indicated the presence of the main absorption peak characteristics of cellulose, hemicellulose, and lignin compositions. X-ray diffraction (XRD) pattern exhibited peaks at $2 \theta=14.9^{\circ}$ and $2 \theta=22^{\circ}$, which are characteristics of cellulose I. Scanning electron microscopy (SEM) showed a rough and heterogeneous surface intercepted by some cavities. Thermogravimetric analysis (TGA) showed more than a thermal decomposition point, suggesting that Nerium fruit is composed of cellulose and noncellulosic matters. The $\mathrm{pH}_{\mathrm{pzc}}$ value of Nerium surface was experimentally determined to be 6.2. Nerium dosage, $\mathrm{pH}$, contact time, dye concentration, and temperature significantly affected the adsorption capacity. The adsorption capacity reached $259 \mathrm{mg} / \mathrm{g}$ at $19{ }^{\circ} \mathrm{C}$. The mean free energy ranged from 74.53 to $84.52 \mathrm{KJ} \mathrm{mol}^{-1}$, suggesting a chemisorption process. Thermodynamic parameters define a chemical, exothermic, and nonspontaneous mechanism. The above data suggest that Nerium fruit can be used as an excellent biomaterial for practical purification of water without the need to impart chemical functionalization on its surface.
\end{abstract}

Keywords: Nerium oleander fruit; cellulose I; methylene blue; adsorption

\section{Introduction}

Contaminated water can be successfully treated by either physical or chemical processes. This can be accomplished using inexpensive and biodegradable alternative adsorbents that decrease the treatment cost of contaminant elimination. In this framework, agricultural waste biomaterials received much attention due to their high availability in nature and low cost. Many biosorbents have been used to remove dyes from water, such as cotton stalks [1], potato wastes [2], peach shells [3], almond shells [4], mandarin peels [5], wood apple shells [6], grape fruit peels [7], peanut hulls [8], peats [9], rice husks [10], wood sawdust [11], peanut husks [12], pine sawdust [13], orange peels [14], banana peels, and coconut mesocarp [15].

Indeed, there are huge amounts of agricultural wastes that are produced on a daily basis. Nerium oleander plant, having a wide geographical distribution, has attracted the attention of researchers 
due to its use in various applications [16-18]. The fruits of Nerium are narrow capsules with a length of 5-23 cm. After maturing, they release soft seed fibers. The use of Nerium fruits and seed fibers as biosorbents of pollutants have not been reported in the literature. In this sense, only the work of Rajab et al. [19] has carried out such study; however, it was restricted to the possibility of utilizing oleander tissues as sorbent material. Our recent studies on Nerium oleander focused on the use of seeds modified with ethylenediamine and hydrazine for the sorption of acid dyes [20]. In addition, we studied the chemical characteristics, dyeing behavior, and abilities of these seed fibers to adsorb cationic dyes [21,22]. Recently, we used Nerium oleander leaves for the ecological synthesis of $\mathrm{CuO}$ nanoparticles, and the prepared particles were applied for the adsorption of methylene blue [23]. Here, the main purpose of the current work was, first, to characterize Nerium oleander fruit and, second, to further evaluate its adsorption capacity for methylene blue under several experimental conditions. Its adsorption performance was checked in relation to that reported in previously published agricultural biosorbents. FTIR, SEM, XRD, and TGA analyses were used to elucidate the functional group characteristics, crystallinity, morphology, and thermal behavior of Nerium fruit. Kinetic theoretical equations were used to understand the affinity between methylene blue as adsorbate and Nerium fruit as adsorbent. The biosorption mechanism on the biomaterial surface was evaluated using the common isotherms of Langmuir, Freundlich, Temkin, and Dubinin.

\section{Experimental}

\subsection{Materials and Reagents}

All chemical reagents used in the current work were of pure grade and used without further purification. Methylene blue, with a molecular weight of $319.85 \mathrm{~g} \mathrm{~mol}^{-1}$, was supplied by a Sigma-Aldrich market. Deionized water was used in diluted colored solutions.

\subsection{Preparation of Nerium oleander Fruit}

Ripe Nerium oleander fruit was cultivated during the period of May-June (Figure 1). Before being characterized and used as adsorbent, the biomass was thoroughly washed with water in order to remove adhering impurities, like sand particles and debris. The dried fruits were further washed with distilled water and dried in an oven at a temperature of $70^{\circ} \mathrm{C}$ for a period of $24 \mathrm{~h}$. The fruits were ground to small powders, washed with distilled water, and finally dried under the abovementioned conditions. Before adsorption investigation, the powdered fruits were stored in airtight bottles.
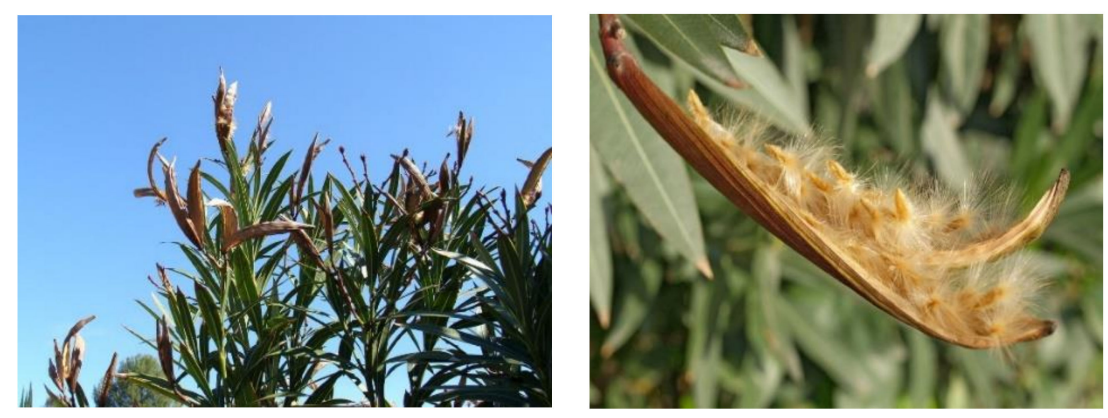

Figure 1. Photographs showing collection of Nerium oleander fruit as agricultural waste.

\subsection{Characterization Instruments}

To elucidate the chemical group characteristics of Nerium oleander fruit, an FTIR spectrum was obtained using a PerkinElmer model (Monastir, Tunisia). A SEM Hitachi S-2360N apparatus (Monastir, Tunisia) was used to observe the morphology of the studied powdered fruit, which was coated with $\mathrm{Au}$ by a vacuum sputter coater with a $20 \mathrm{kV}$ accelerating voltage. X-ray powder diffraction was performed at ambient temperature using a PANalytical X'Pert PRO MPD apparatus (Malvern, UK). 
Thermogravimetric analysis (TGA) was performed in air flow at a heating level of $10^{\circ} / \mathrm{min}$ using a NETZSCH STA 449F3 equipment (Selb, Germany).

The point of zero charge $\left(\mathrm{pH}_{\mathrm{PZC}}\right)$ of powdered Nerium fruit was obtained by the addition of $\mathrm{KNO}_{3}$ solution: $0.1 \mathrm{~g}$ of solid biosorbent was immersed in $10^{-1} \mathrm{M} \mathrm{KNO}_{3}$ solutions $(50 \mathrm{~mL})$ at different $\mathrm{pH}$ values. The initial $\mathrm{pH}$ was maintained in the range $2-11$ by the addition of either $\mathrm{HCl}$ or $\mathrm{NaOH}$ under magnetic agitation for $48 \mathrm{~h}$. The final $\mathrm{pH}$ value was plotted versus the initial $\mathrm{pH}$ value. The $\mathrm{pH}$ PZC was registered when the point $\mathrm{pH}_{\text {final }}=\mathrm{pH}_{\text {initial }}$ [24].

\subsection{Biosorption Experiments}

Batch biosorption experiments were performed in Erlenmeyer flasks using $20 \mathrm{~mL}$ of methylene blue solution and $0.025 \mathrm{~g}$ of powdered Nerium fruit. The biosorbent dosages were studied in the range $1.25-7.5 \mathrm{~g} / \mathrm{L}$. The isotherm experiments were conducted at 19,40 , and $55^{\circ} \mathrm{C}$. The kinetic essays were studied in the range 0-120 min. After each experiment, the solutions were filtered through filter papers, and the absorbance of the remaining solution was determined spectrophotometrically at $\lambda_{\max }=665 \mathrm{~nm}$ corresponding to the maximum absorbance of methylene blue. The adsorption capacity was calculated using the following equation:

$$
q(m g / g)=\frac{(\mathrm{c} 0-\mathrm{ce})}{\mathrm{m}} \times \mathrm{V}
$$

where $\mathrm{c} 0$ is the initial dye concentration, ce is the remaining solution, $\mathrm{V}$ is the used volume of dye for each experiment, and $\mathrm{m}$ is the mass of the used biosorbent.

To describe the biosorption mechanism of methylene blue using powdered Nerium fruit, the experimental results were correlated with the theoretical isotherms of Langmuir, Freundlich, Temkin, and Dubinin, which are generally used to clarify the mechanism of biosorption as well as the heterogeneity of the biosorbent surface [24].

\section{Results and Discussion}

\subsection{Characterization of Nerium oleander Fruit}

FTIR spectroscopy can afford information about the reactive groups existing on the surface of Nerium fruit that provide adsorptive sites for methylene blue molecules. Figure 2 displays the main absorption peaks registered within the studied biomaterial. The broad intense absorption peak around $3392 \mathrm{~cm}^{-1}$ is attributed to the hydroxyl groups. The bands at 2959 and $2914 \mathrm{~cm}^{-1}$ correspond to $\mathrm{C}-\mathrm{H}$ stretching of the $-\mathrm{CH}_{3}$ and $-\mathrm{CH}_{2}$ groups, respectively $[25,26]$. The peaks at $2100-2200 \mathrm{~cm}^{-1}$ show the presence of $\mathrm{CO}_{2}$ in normal air. The peak at $1743 \mathrm{~cm}^{-1}$ confirms the functional $\mathrm{C}=\mathrm{O}$ group present in hemicelluloses $[25,26]$. The absorption peaks registered at $1624-1548 \mathrm{~cm}^{-1}$ are attributed to the $\mathrm{C}=\mathrm{C}$ aromatic groups in the lignin $[27,28]$. The absorption peak at $1446 \mathrm{~cm}^{-1}$ is assigned to the angular deformation of the $-\mathrm{CH}$ groups in the cellulose structure [27]. The peak observed at $1320-1327 \mathrm{~cm}^{-1}$ corresponds to the angular deformation of the $-\mathrm{CH}$ groups in hemicelluloses [28]. The peak at $1038 \mathrm{~cm}^{-1}$ may be assigned to the $\mathrm{C}-\mathrm{O}$ symmetric or asymmetric vibration (-C-O-C- ring) of the cellulose. The peak at $783 \mathrm{~cm}^{-1}$ is related to the out-of-plane angular deformation of the $-\mathrm{CH}$ groups in substituted aromatic rings [29]. The majority of these peaks indicate that Nerium oleander fruit is rich in massive oxygenous groups on its surface [26], which could be responsible for the interaction between methylene blue and the biomaterial through hydrogen bonding. In Scheme 1, a suggested mechanistic pathway for interactions between methylene blue and Nerium oleander fruit surface is depicted. Indeed, the hydroxyl groups of the biomaterial could easily react to the nitrogen atom of methylene blue through hydrogen bonding. 


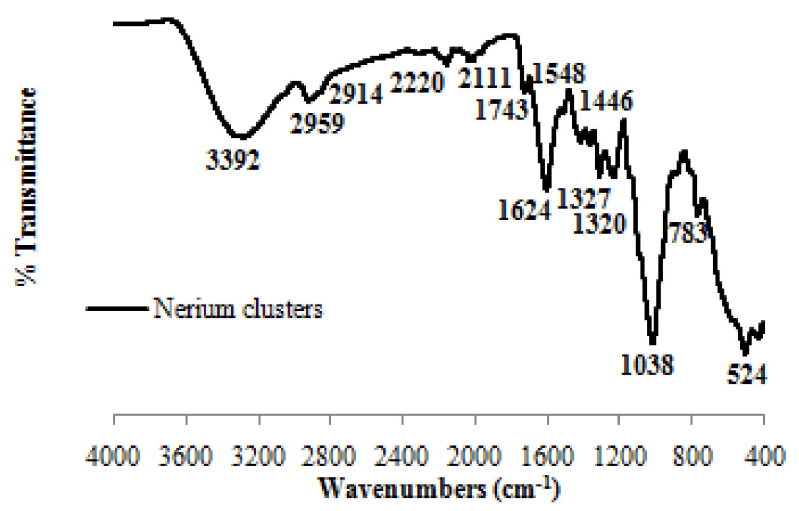

Figure 2. FTIR spectrum of Nerium oleander fruit.

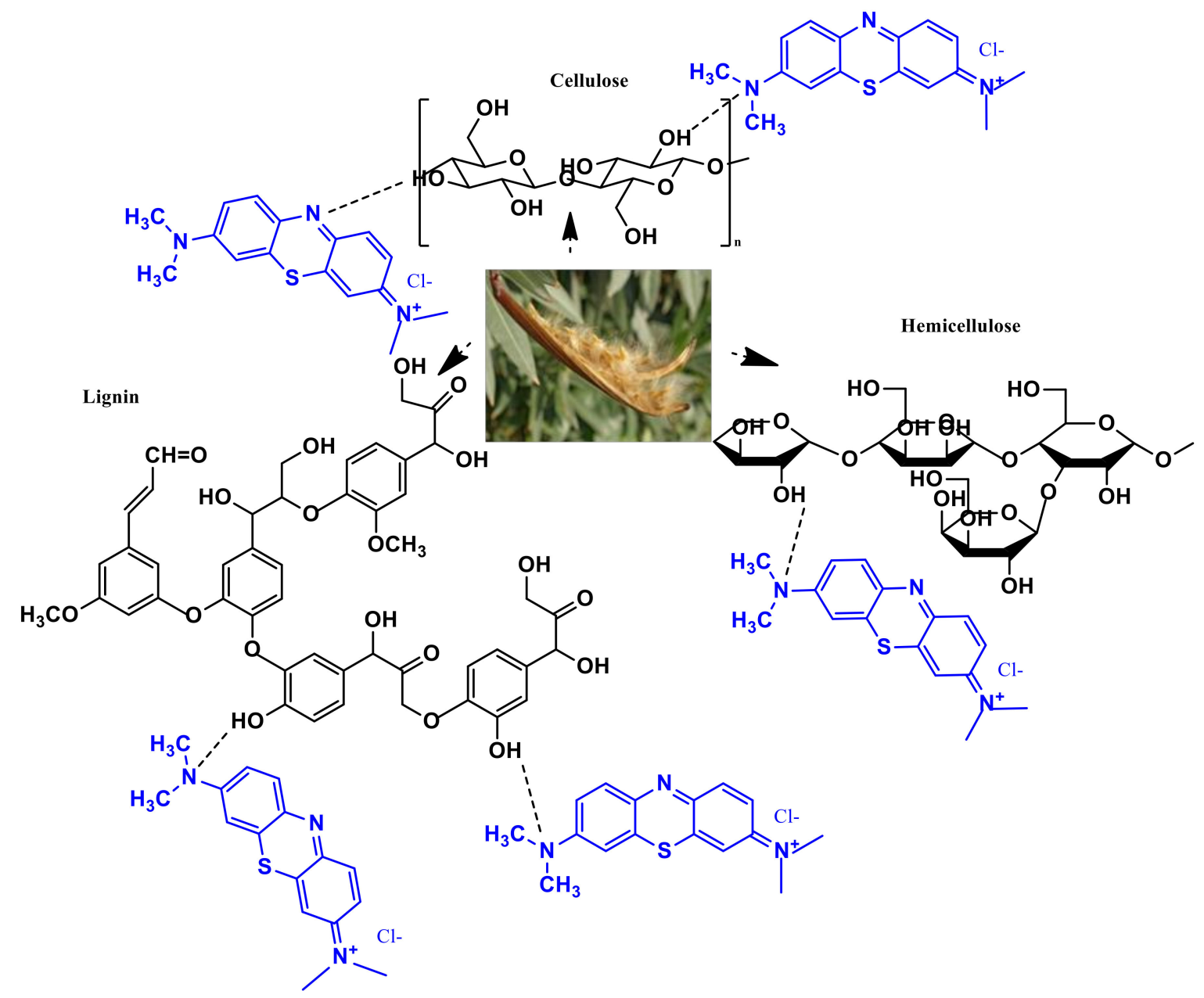

Scheme 1. Proposed mechanistic pathway for interactions between methylene blue and Nerium oleander fruit surface.

Powder X-ray diffraction was used to describe the powdered Nerium oleander fruit by scanning in the range $10^{\circ}-90^{\circ}\left(2 \theta^{\circ}\right)$ (Figure 3$)$. The biomaterial exhibited the characteristic diffraction peaks at $2 \theta=14.9^{\circ}$ (amorphous phase) and $2 \theta=22^{\circ}$ (crystalline phase). According to the literature, these peaks are characteristics of crystal planes (110) and (200) of cellulose I [30,31]. The strong peak observed at $2 \theta=14.9^{\circ}$ indicates the presence of a high proportion of noncellulose compositions [32,33]. These main peaks were also observed in our previous paper [22] when reporting XRD patterns of the seed fibers 
encapsulated in the narrow capsules of Nerium oleander plant. The presence of other small peaks could be attributed to the existence of inorganic matters.

SEM images (Figure 4), given at different higher magnifications $(\times 500$ and $\times 1600)$, showed a rough and heterogeneous surface of Nerium oleander fruit with the existence of some cavities. These precise morphological characteristics could easily facilitate the interaction between the studied solid biomaterial as biosorbent and methylene blue as adsorbate.

Thermal analysis was carried out to study the decomposition pattern and thermal stability of Nerium fruit. The TGA curve of Nerium fruit is depicted in Figure 5. Many thermal decomposition points were observed at different temperature values. The maximum mass loss reached $75 \%$. This indicates that the studied biomaterial was composed of cellulose and noncellulosic matters. This behavior agrees well with the results gleaned from FTIR, XRD, and SEM analyses. A weight loss of $8 \%$ was observed at $93{ }^{\circ} \mathrm{C}$, which could generally be ascribed to the moisture evaporation on the surface and inside the biomaterial [34,35]. The thermal decomposition observed at $243{ }^{\circ} \mathrm{C}$ could be assigned to the decomposition of the organic compounds, including cellulose and noncellulosic matters, found in the biomaterial $[36,37]$. The thermal decomposition at $385^{\circ} \mathrm{C}$ could be due to the depolymerization and decomposition of glycosyl units [38]. The slight decomposition observed at $544-711^{\circ} \mathrm{C}$ may be associated with the degradation of inorganic compounds existing in native fruits.

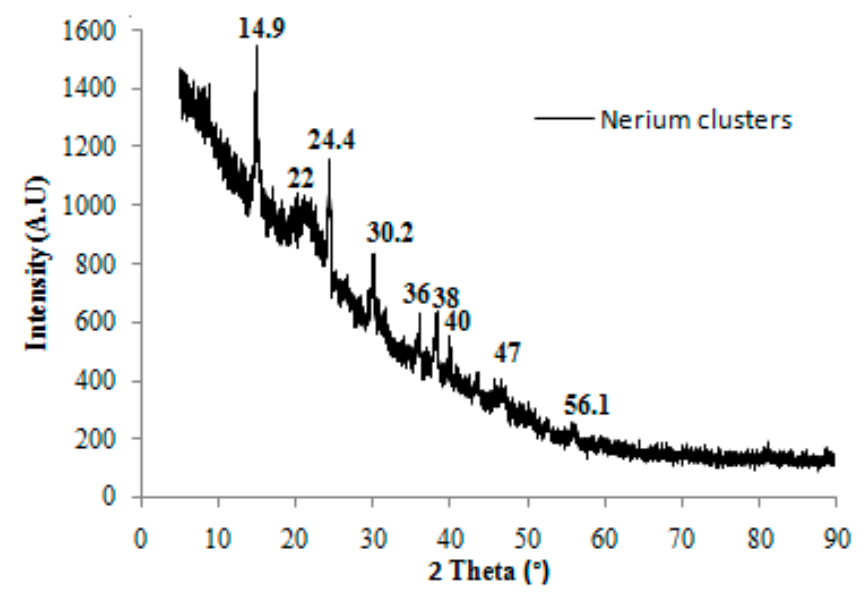

Figure 3. XRD patterns of Nerium oleander fruit.

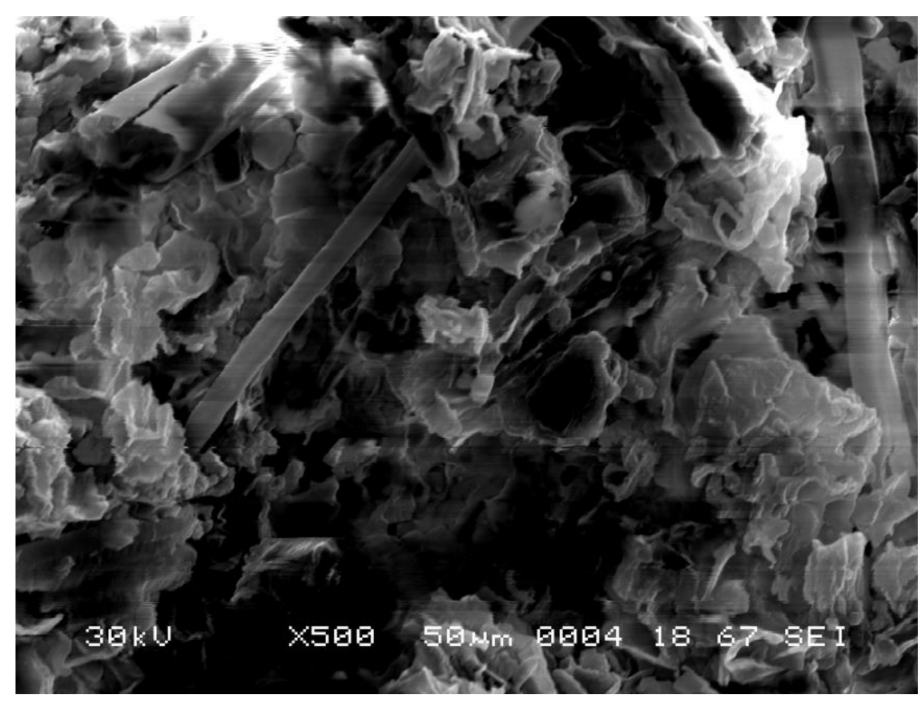

Figure 4. Cont. 


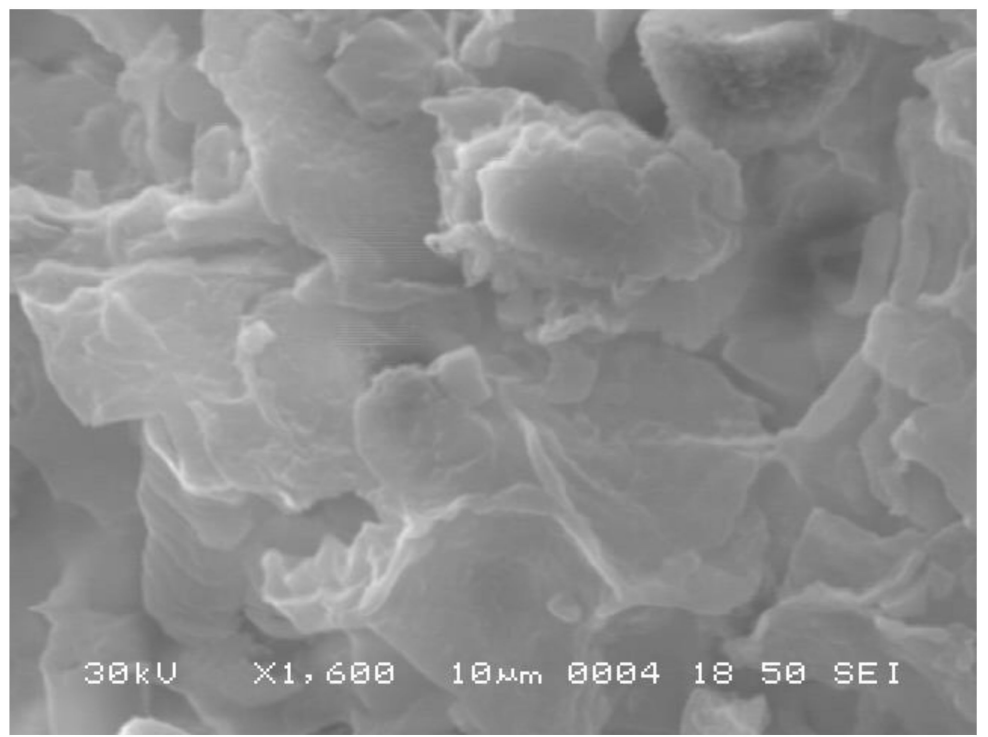

Figure 4. SEM images of Nerium oleander fruit.

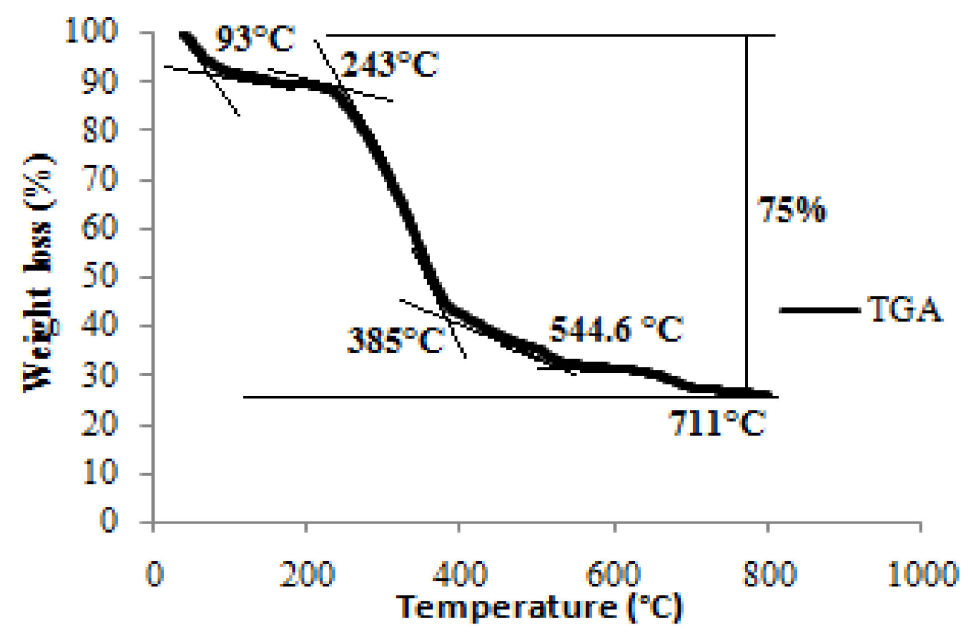

Figure 5. TGA curve of Nerium oleander fruit.

\subsection{Factors Affecting the Adsorption of Methylene Blue}

\subsubsection{Effect of Experimental Parameters on Adsorption Performance}

Figure 6a gives a plot of the initial $\mathrm{pH}$ against the final $\mathrm{pH}$. The $\mathrm{pH}_{\mathrm{pzc}}$ value of Nerium oleander fruit was determined to be 6.2. This finding suggests that the surface of the biomaterial was positive at $\mathrm{pH}<6.2$ [39]. However, it became negatively charged at $\mathrm{pH}>6.2$, therefore permitting an electrostatic attraction with the cationic methylene blue. Indeed, methylene blue dye can easily dissociate in water, giving $\mathrm{MB}^{+}$and $\mathrm{Cl}^{-}$ions [40].

The biosorption of methylene blue using Nerium oleander fruit was investigated in the $\mathrm{pH}$ range 3-11 (Figure 6b). The results indicate that a low biosorption capacity was reached at high acidic conditions. The highest adsorption capacity was achieved at $\mathrm{pH} \mathrm{6,} \mathrm{above} \mathrm{which} \mathrm{a} \mathrm{decrease} \mathrm{was}$ observed. This finding agrees well with the $\mathrm{pH}_{\mathrm{pzc}}$ determined experimentally (Figure 6a). Based on FTIR and XRD results, Nerium fruit has many oxygenous groups as adsorption sites on the surface, therefore allowing different trends at different $\mathrm{pH}$ values. Positive charges were acquired by the Nerium surface at an acidic $\mathrm{pH}$ due to protonation, and a negative charge was acquired due to deprotonation of oxygenous groups at alkaline conditions. At acidic $\mathrm{pH}$ values, the positively charged methylene blue 
ions opposed the positively charged Nerium surface, leading to low biosorption amounts. At higher $\mathrm{pH}$ values, the biosorbent surface became negative, favoring an electrostatic interaction with methylene blue. In this case, it was observed that the biosorption tendency of Nerium fruit increased with an increase in $\mathrm{pH}$ due to an increase in the deprotonation of the oxygenous groups of the adsorbent. Quite similar behaviors were observed and reported in other previous published works [24,41-43].
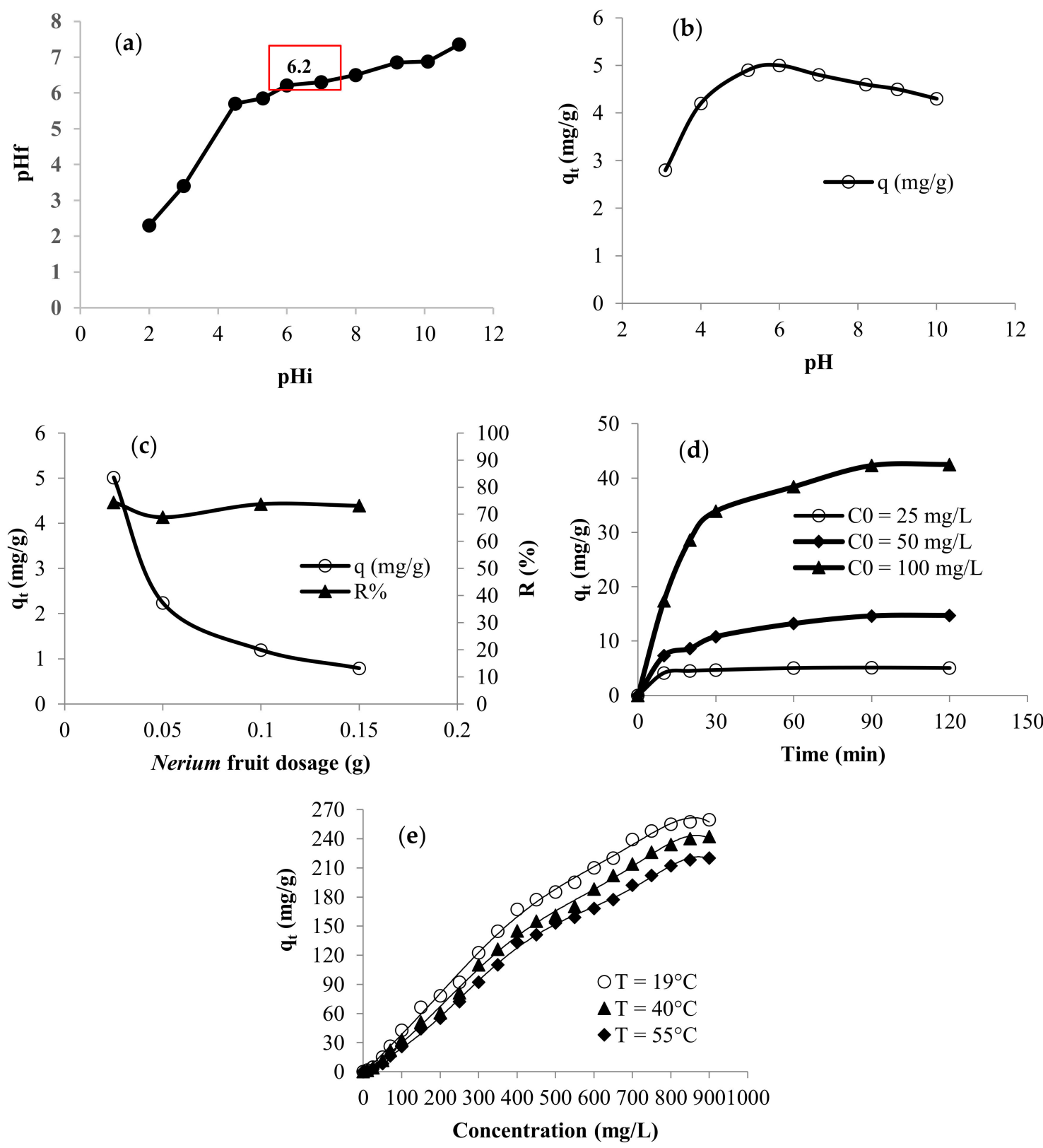

Figure 6. Influence of some experimental parameters on the biosorption of methylene blue using Nerium fruit: (a) plots of $\mathrm{pH}$ final versus $\mathrm{pH}$ initial, (b) effect of $\mathrm{pH}$ value, (c) evolution of adsorbent dosage, (d) variation of time, (e) change of methylene blue concentration, and temperature.

Figure $6 \mathrm{c}$ indicates that the adsorption of methylene blue using Nerium fruit was affected by the change of adsorbent dosages ranging from 1 to $6 \mathrm{~g} \mathrm{~L}^{-1}$. The maximum adsorbed amount of methylene blue was observed with $1 \mathrm{~g} \mathrm{~L}^{-1}$ of Nerium fruit, and further added biosorbent decreased the adsorption of methylene blue. The high degree of removal of methylene blue registered at the lowest adsorbent dosage may be attributed to the large adsorption sites of the Nerium fruit surface [44]. 
The plots representing the evolution of adsorbed methylene blue versus contact time (Figure 6d) indicate that about $80 \%$ of dye molecules were removed within the first $30 \mathrm{~min}$ and attained equilibrium at $90 \mathrm{~min}$. The explanation of this behavior is that, at the initial period of time, many vacant active sites were available at the surface of Nerium fruit, which were responsible for the rapid adsorption of methylene blue molecules. But after this stage, the surface of the biosorbent became partially filled, and therefore, the number of available active sites on the surface of the adsorbent decreased [45].

Figure 6e shows that Nerium fruit has good adsorption capacities at low concentrations of methylene blue. This trend suggests that large active sites on the adsorbents are accessible at this stage. At high dye concentration, the adsorption capacity reached approximately its maximum. This suggests that the interstitial spaces in the solid adsorbent became more saturated. Indeed, the adsorption occurred synchronously on the surface and in the inner section of the adsorbent. Due to prior contact, adsorption proceeded on the surface during the first stage. Then, the active sites on the surface of the adsorbent reacted with the liquid to reach saturation. Consequently, high dye concentrations could easily saturate the surface adsorption sites. At $19{ }^{\circ} \mathrm{C}$, the maximum adsorbed amount of methylene blue was reached at $259 \mathrm{mg} / \mathrm{g}$. Compared with other studied biosorbents published in the literature (Table 1), this level is too high, and the studied biomaterial could be valorized as an excellent biosorbent to treat colored solutions.

Table 1. A comparison of the biosorption capacities of methylene blue using some biomaterials published in the literature.

\begin{tabular}{|c|c|c|c|}
\hline Adsorbent & Target & $\begin{array}{l}\text { Maximum Adsorption } \\
\text { Capacity }\left(\mathrm{mg} \mathrm{g}^{-1}\right)\end{array}$ & Reference \\
\hline Nerium fruits & Methylene blue & 259 & Current work \\
\hline Pineapple stem & Methylene blue & 119 & [46] \\
\hline Lotus leaf & Methylene blue & 221.7 & [47] \\
\hline Palm tree waste & Methylene blue & 39.47 & [48] \\
\hline Pinus durangensis & Methylene blue & 85 & [49] \\
\hline Salix babylonica leaves & Methylene blue & 60.97 & [50] \\
\hline Kenaf core fibers & Methylene blue & 131.6 & [51] \\
\hline Almond shell & Methylene blue & 84.9 & [4] \\
\hline Prickly (peel) bark of cactus fruit & Methylene blue & 222 & [52] \\
\hline Algae Sargassum muticum & Methylene blue & 279.2 & {$[53]$} \\
\hline Broad been peals & Methylene blue & 192.7 & [54] \\
\hline Algae Gelidium & Methylene blue & 171 & [55] \\
\hline Rejected tea & Methylene blue & 147 & [56] \\
\hline Mango seed kernel & Methylene blue & 142.9 & [57] \\
\hline Empty fruit bunch & Methylene blue & 50.76 & [58] \\
\hline Rice husk & Methylene blue & 40.6 & [59] \\
\hline Orange peel & Methylene blue & 18.6 & {$[60]$} \\
\hline Jute processing waste & Methylene blue & 22.47 & [61] \\
\hline Garlic peel & Methylene blue & 82.64 & {$[62]$} \\
\hline Date pits & Methylene blue & 80.31 & [63] \\
\hline Walnut shell powder & Methylene blue & 178.9 & {$[64]$} \\
\hline Dead Typha angustifolia (L.) leaves & Methylene blue & 106.75 & [24] \\
\hline Peach shells & Methylene blue & 183.6 & [3] \\
\hline
\end{tabular}


The adsorption of methylene blue using Nerium fruit is also affected by a change in temperature (Figure 6e). Results obtained indicate a decrease in methylene blue adsorption capacity with an increase in temperature. This trend is due to the escape of the adsorbed methylene blue ions with increasing energy or temperature.

\subsubsection{Kinetic Modeling}

Kinetic data are important to understanding the affinity between methylene blue as adsorbate and Nerium fruit as adsorbent at equilibrium. In fact, this study could provide sufficient information on the biosorption mechanism, and it suggests whether it is physical and/or chemical and mass transport. The adsorption of methylene blue using Nerium fruit was analyzed using the pseudo-first-order (Figure 7a), pseudo-second-order (Figure 7b), Elovich (Figure 7c), and intraparticular diffusion (Figure 7d) equations. With reference to the obtained curves, the kinetic parameters were computed and are summarized in Table 2. Following the data registered within the pseudo-first-order equation, we observed that the $\mathrm{R}^{2}$ values ranged from 0.86 to 0.95 . These low values suggest that this equation cannot describe the kinetic data perfectly. Indeed, this equation does not follow well the whole range of time, and it was valid only during the initial stage of adsorption [65]. However, the correlation coefficients obtained within the pseudo-second-order equation were greater than 0.99 , which suggests that the adsorption of methylene blue using Nerium fruit can be considered a chemisorption process [66]. In addition, the high regression coefficient values $\left(0.94<R^{2}<0.98\right)$ registered in the case of the Elovich equation suggest a chemisorption with heterogeneous pores on the surface of the adsorbent. The plots for the intraparticle diffusion model are obviously diverged from the origin, suggesting that this equation is not the sole rate-controlling step but that other kinetic processes could occur during the adsorption [67].

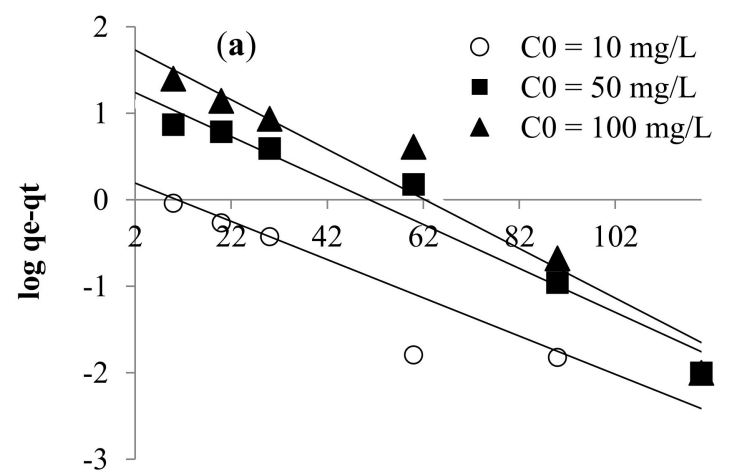

Time (min)

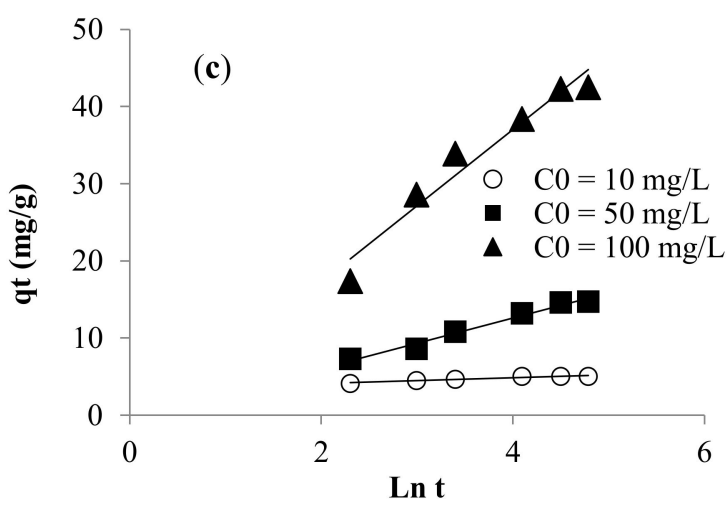

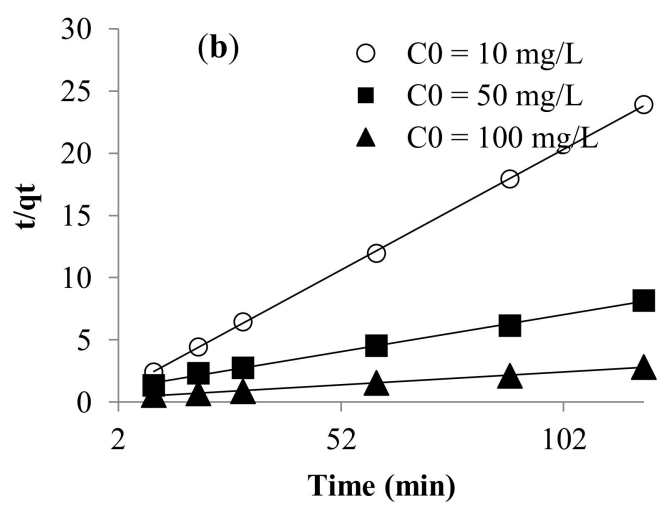

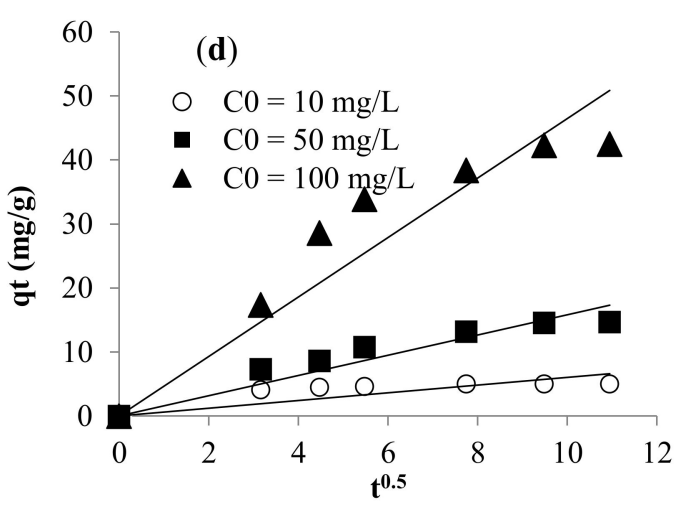

Figure 7. Kinetic adsorption data of methylene blue using Nerium fruit linearized through (a) pseudo-first-order, (b) pseudo-second-order, (c) Elovich, and (d) intraparticular diffusion equations. 


\subsubsection{Isotherm Study and Thermodynamic Parameter Calculation}

The relationship between Nerium oleander fruit and methylene blue was analyzed using the isotherms of Langmuir, Freundlich, Temkin, and Dubinin-Radushkevich (Figure 8a-d). The fitting parameters are summarized in Table 2. As observed, the equation of Freundlich fitted better the adsorption data $\left(0.98 \leq \mathrm{R}^{2}\right)$ compared with the other studied equations. The consistency of the Freundlich equation with the data revealed that the adsorption may occur in the heterogeneous adsorption sites. The adsorption energy constant (B) determined from the Temkin equation decreased from 68.4 to 57.2 when the temperature rose from 19 to $55^{\circ} \mathrm{C}$. This decrease of the adsorbed quantity of methylene blue with an increase in temperature agrees with the data described above. The values of the heat of sorption were high $(\mathrm{bt}=35.48 .5-47.69 \mathrm{~J} / \mathrm{mol})$, suggesting a chemical adsorption process [68]. The mean free energy values, calculated from the Dubinin equation, ranged from 74.53 to $84.52 \mathrm{KJ} \mathrm{mol}^{-1}$. These values are greater than $40 \mathrm{KJ} \mathrm{mol}^{-1}$, suggesting a chemisorption mechanism [69].

The negative value of the enthalpy $\left(\Delta \mathrm{H}^{\circ}=-27.05 \mathrm{~kJ} / \mathrm{mol}\right)$ proves that the interaction between Nerium fruit and methylene blue is exothermic. This result agrees with the decrease of the adsorbed capacity with temperature. The negative value of the entropy change $\left(\Delta S^{\circ}=-153.75 \mathrm{~J} / \mathrm{mol}\right)$ suggests a decrease of the disorder and randomness at the solid-solution interface of methylene blue with Nerium oleander clusters. The positive values of the free energy $\left(\Delta \mathrm{G}^{\circ}=17.84-23.37 \mathrm{~kJ} / \mathrm{mol}\right)$ indicate that the biosorption mechanism is nonspontaneous. 
Table 2. Summarized kinetic constants, Langmuir, Freundlich, Temkin, and Dubinin parameters for the adsorption of methylene blue using powdered fruit derived from Nerium oleander.

\begin{tabular}{|c|c|c|c|c|c|c|c|c|c|}
\hline Kinetic equations & \multirow{2}{*}{ Constants } & \multicolumn{3}{|c|}{ Dye concentration (mg/L) } & \multirow[b]{2}{*}{ Isotherms } & \multirow{2}{*}{ Parameters } & \multicolumn{3}{|c|}{ Temperature $\left({ }^{\circ} \mathrm{C}\right)$} \\
\hline \multirow{4}{*}{ Pseudo-first-order } & & 10 & 50 & 100 & & & 19 & 40 & 55 \\
\hline & $\mathrm{K}_{1}\left(\min ^{-1}\right)$ & 0.022 & 0.025 & 0.028 & & $\mathrm{q}_{\mathrm{m}}\left(\mathrm{mg} \mathrm{g}^{-1}\right)$ & 769.23 & 1111.11 & 1666.67 \\
\hline & $\mathrm{q}\left(\mathrm{mg} \mathrm{g}^{-1}\right)$ & 1.716 & 19.40 & 61.23 & \multirow{2}{*}{ Langmuir } & $\mathrm{K}_{\mathrm{L}}\left(\mathrm{Lg}^{-1}\right)$ & 0.000623 & 0.000331 & 0.00018 \\
\hline & $\mathrm{R}^{2}$ & 0.86 & 0.96 & 0.95 & & $\mathrm{R}^{2}$ & 0.91 & 0.74 & 0.61 \\
\hline \multirow{4}{*}{ Pseudo-second-order } & $\mathrm{K}_{2}$ & 0.0735 & 0.0037 & 0.0014 & \multirow{3}{*}{$\begin{array}{c}\text { Thermodynamic } \\
\text { parameters }\end{array}$} & $\Delta \mathrm{H}^{\circ}\left(\mathrm{KJ} \mathrm{mol}^{-1}\right)$ & & -27.05 & \\
\hline & $\mathrm{q}\left(\mathrm{mg} \mathrm{g}^{-1}\right)$ & 5.154 & 16.806 & 48.309 & & $\Delta \mathrm{S}^{\circ}\left(\mathrm{J} \mathrm{mol}^{-1}\right)$ & & -153.75 & \\
\hline & $\mathrm{h}$ & 1.954 & 1.052 & 3.245 & & $\Delta \mathrm{G}^{\circ}\left(\mathrm{KJ} \mathrm{mol}^{-1}\right)$ & 17.84 & 21.07 & 23.37 \\
\hline & $\mathrm{R}^{2}$ & 0.999 & 0.997 & 0.997 & \multirow{3}{*}{ Freundlich } & $\mathrm{K}_{\mathrm{F}}\left(\mathrm{L} \mathrm{g}^{-1}\right)$ & 0.185 & 0.135 & 0.080 \\
\hline \multirow{3}{*}{ Elovich } & $\left(\mathrm{mg} \mathrm{g}^{-1} \min ^{-1}\right)$ & 2656.25 & 2.807 & 7.648 & & $\mathrm{n}$ & 0.902 & 0.878 & 0.831 \\
\hline & $\beta\left(\mathrm{mg} \mathrm{g}^{-1} \mathrm{~min}^{-1}\right)$ & 2.65 & 0.305 & 0.1011 & & $\mathrm{R}^{2}$ & 0.98 & 0.98 & 0.98 \\
\hline & $\mathrm{R}^{2}$ & 0.938 & 0.978 & 0.948 & \multirow{4}{*}{ Temkin } & $\mathrm{B}(\mathrm{J} / \mathrm{mol})$ & 68.407 & 62.665 & 57.173 \\
\hline \multirow{7}{*}{$\begin{array}{l}\text { Intraparticular } \\
\text { diffusion }\end{array}$} & $\mathrm{K}\left(\mathrm{mg} \mathrm{g}^{-1} \min ^{1 / 2}\right)$ & 0.606 & 1583 & 4.645 & & $A\left(\mathrm{~L} \mathrm{~g}^{-1}\right)$ & 0.0314 & 0.0296 & 0.0287 \\
\hline & & & 1.000 & & & bt $(\mathrm{J} / \mathrm{mol})$ & 35.48 & 41.53 & 47.69 \\
\hline & $\mathrm{R}^{2}$ & 0.339 & 0.876 & 0.848 & & $\mathrm{R}^{2}$ & 0.87 & 0.85 & 0.84 \\
\hline & & & & & \multirow{4}{*}{ Dubinin } & $\mathrm{q}\left(\mathrm{mg} \mathrm{g}^{-1}\right)$ & 115.85 & 100.35 & 87.11 \\
\hline & & & & & & $\mathrm{E}(\mathrm{KJ} / \mathrm{mol})$ & 74.536 & 79.057 & 84.52 \\
\hline & & & & & & $\mathrm{K}_{\mathrm{DR}}\left(\mathrm{mol}^{2} / \mathrm{kJ}^{2}\right)$ & $9 \times 10^{-5}$ & $8 \times 10^{-5}$ & $7 \times 10^{-5}$ \\
\hline & & & & & & $\mathrm{R}^{2}$ & 0.55 & 0.54 & 0.53 \\
\hline
\end{tabular}



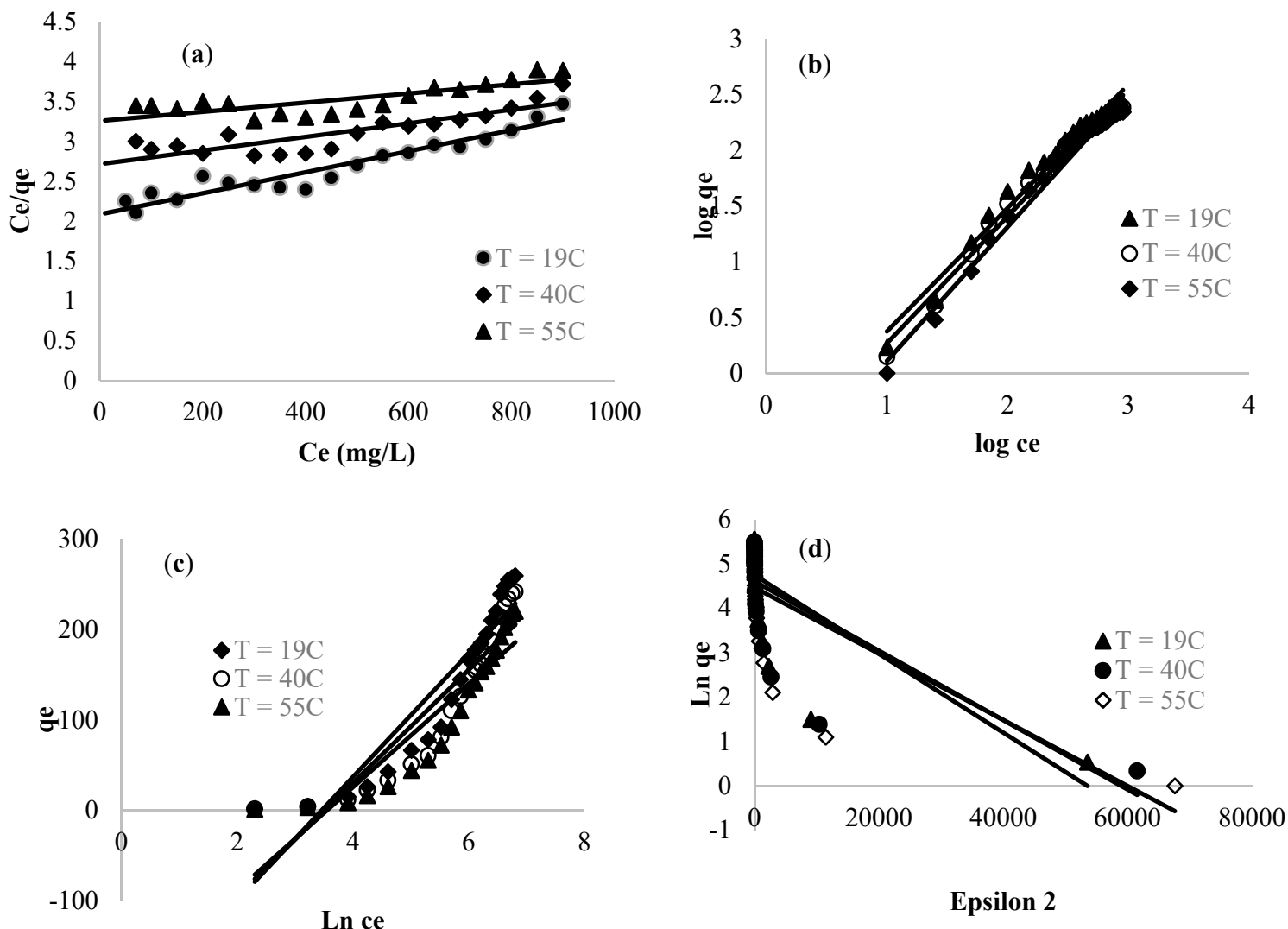

(e)

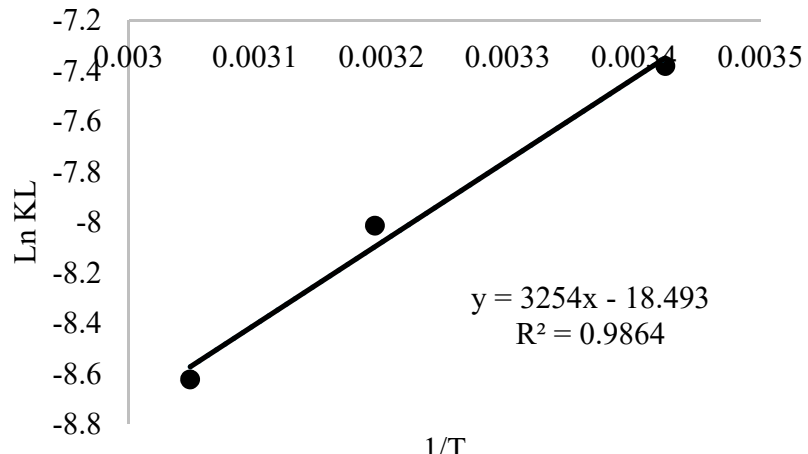

Figure 8. Linearization of the adsorption data of methylene blue using Nerium fruit through (a) Langmuir, (b) Freundlich, (c) Temkin, (d) Dubinin isotherms, and (e) plots of Ln Kl versus the inverse of temperature.

\section{Conclusions}

The results presented herein focused on the characterization and application of Nerium oleander fruit as a biomaterial for the adsorption of methylene blue from aqueous solution. FTIR spectroscopy indicated the presence of the main absorption peak characteristics of cellulose and noncellulose compositions. XRD patterns showed the characteristics of cellulose I composition. SEM features showed a rough and heterogeneous Nerium surface. TGA analysis indicated that Nerium fruit is composed of cellulose and noncellulosic matters. The adsorption capacity reached $259 \mathrm{mg} / \mathrm{g}$ at room temperature, which constitutes a high level of capacity compared with other published biosorbents. The values of the mean free energy calculated by the Dubinin isotherm were 74.53 to $84.52 \mathrm{KJ} \mathrm{mol}^{-1}$, 
suggesting a chemisorption mechanism. It was found that adsorption capacity depends on several experimental parameters, including $\mathrm{pH}$, adsorbent dosage, temperature, etc. The thermodynamic study indicates that the adsorption process was chemical, exothermic, and nonspontaneous. Future work will concern the design of biocomposites based on this material for versatile applications.

Author Contributions: Y.O.A.-G.: Methodology, Software, Data curation, Writing-Original draft preparation. M.J.: Visualization, Investigation, Supervision Software, Validation, Writing-Reviewing and Editing, R.S.: Data curation, Visualization, Investigation, Supervision Software, Validation. S.A.K.: Data curation, Visualization, Investigation, Validation. All authors have read and agreed to the published version of the manuscript.

Funding: The authors extend their appreciation to the deputyship for Research \& Innovation, Ministry of Education in Saudi Arabia for funding this research work through project number (IFP-2020-15).

Acknowledgments: The authors extend their appreciation to the deputyship for Research \& Innovation, Ministry of Education in Saudi Arabia for funding this research work through project number (IFP-2020-15).

Conflicts of Interest: The authors declare no conflict of interest.

\section{References}

1. Deng, H.; Lua, J.; Li, G.; Zhang, G.; Wang, X. Adsorption of methylene blue on adsorbent materials produced from cotton stalk. Chem. Eng. J. 2011, 172, 326-334. [CrossRef]

2. Gupta, N.; Kushwaha, A.K.; Chattopadhyaya, M.C. Application of potato (Solanum tuberosum) plant wastes for the removal of methylene blue and malachite green dye from aqueous solution. Arab. J. Chem. 2011, 9,707-716. [CrossRef]

3. Markovic, S.; Stankovic, A.; Lopicic, Z.; Lazarevic, S.; Stojanovic, M.; Uskoković, D. Application of raw peach shell particles for removal of methylene blue. J. Environ. Chem. Eng. 2015, 3, 716-724. [CrossRef]

4. Jabli, M.; Gamha, E.; Sebeia, N.; Hamdaoui, M. Almond shell waste (Prunus dulcis): Functionalization with [dimethy-diallyl-ammonium-chloride-diallylamin-co-polymer] and chitosan polymer and its investigation in dye adsorption. J. Mol. Liq. 2017, 240, 35-44. [CrossRef]

5. Pavan, F.A.; Gushikem, Y.; Mazzocato, A.S.; Dias, S.L.P.; Lima, E.C. Statistical design of experiments as tool for optimizing the batch conditions to methylene blue adsorption on yellow passion fruit and mandarin peels. Dye. Pigment. 2007, 72, 256-266. [CrossRef]

6. Jain, S.; Jayaram, R.V. Removal of basic dyes from aqueous solution by low-cost adsorbent: Wood apple shell (Feronia acidissima). Desalination 2010, 250, 921-927. [CrossRef]

7. Saeed, A.; Sharif, M.; Iqbal, M. Application potential of grapefruit peel as dye sorbent: Kinetics, equilibrium and mechanism of crystal violet adsorption. J. Hazard. Mater. 2010, 179, 564-572. [CrossRef]

8. Gong, R.M.; Li, M.; Yang, C.; Sun, Y.Z.; Chen, J. Removal of cationic dyes from aqueous solution by adsorption on peanut hull. J. Hazard. Mater. 2005, 121, 247-250. [CrossRef]

9. Allen, S.J.; Mckay, G.; Porter, J.F. Adsorption isotherm models for basic dye adsorption by peat in single and binary component systems. J. Colloid Interface Sci. 2004, 280, 322-333. [CrossRef]

10. Han, R.P.; Ding, D.D.; Xu, Y.F.; Zou, W.H.; Wang, Y.F.; Li, Y.F.; Zou, L.N. Use of rice husk for the adsorption of Congo red from aqueous solution in column mode. Bioresour. Technol. 2008, 99, 2938-2946. [CrossRef]

11. Jain, R.; Sikarwar, S. Removal of hazardous dye Congo red from waste material. J. Hazard. Mater. 2008, 152, 942-948. [CrossRef]

12. Sadaf, S.; Bhatti, H.N. Batch and fixed bed column studies for the removal of Indosol Yellow BG dye by peanut husk. J. Taiwan Inst. Chem. Eng. 2014, 45, 541-553. [CrossRef]

13. Ozacar, M.; Sengil, I.A. Adsorption of metal complex dyes from aqueous solution by pine sawdust. Bioresour. Technol. 2005, 96, 791-795. [CrossRef]

14. Aramiab, M.; Limaeea, N.Y.; Mahmoodia, N.M.; Tabrizia, N.S. Removal of dyes from colored textile wastewater by orange peel adsorbent: Equilibrium and kinetic studies. J. Colloid Interface Sci. 2005, 288, 371-376. [CrossRef]

15. Nascimento, G.E.; Campos, N.F.; Silva, J.J.; Barbosa, C.M.B.M.; Duarte, M.M.M.B. Adsorption of anionic dyes from an aqueous solution by banana peel and green coconut mesocarp. Desalination Water Treat. 2015, 57, 14093-14108. [CrossRef]

16. Erdremoglu, N.; Küpeli, E.; Yeşilada, E. Anti-inflammatory and antinociceptive activity assessment of plants used as remedy in Turkish folk medicine. J. Ethnopharmacol. 2003, 89, 123-129. [CrossRef] 
17. Kumar, S.; Anand, G.R. Evaluation of anti-inflammatory activity of Nerium oleander. Pharmacia 2010, 1, 33-36.

18. El Sawi, N.M.; Geweely, N.S.; Qusti, S.; Mohamed, M.; Kamel, A. Cytotoxicity and antimicrobial activity of Nerium oleander extracts. J. App. Anim. Res. 2010, 37, 25-31. [CrossRef]

19. Abu-El-Halawa, R.; Zabin, S.A.; Abu-Sittah, H.H. Investigation of Methylene Blue Dye Adsorption from Polluted Water Using Oleander Plant (Al Defla) Tissues as Sorbent. Am. J. Environ. Sci. 2016, 12, 213-224. [CrossRef]

20. Jabli, M.; Tka, N.; Salman, G.A.; Elaissi, A.; Sebeia, N.; Hamdaoui, M. Rapid interaction, in aqueous media, between anionic dyes and cellulosic Nerium oleander fibers modified with Ethylene-Diamine and Hydrazine. J. Mol. Liq. 2017, 242, 272-283. [CrossRef]

21. Jabli, M.; Tka, N.; Ramzi, K.; Saleh, T.A. Physicochemical characteristics and dyeing properties of lignin-cellulosic fibers derived from Nerium oleander. J. Mol. Liq. 2018, 249, 1138-1144. [CrossRef]

22. Sebeia, N.; Jabli, M.; Ghith, A.; ElGhoul, Y.; Alminderej, F.M. Populus tremula, Nerium oleander and Pergularia tomentosa seed fibers as sources of cellulose and lignin for the bio-sorption of methylene blue. Int. J. Biol. Macromol. 2019, 121, 655-665. [CrossRef] [PubMed]

23. Sebeia, N.; Jabli, M.; Ghith, A. Biological synthesis of copper nanoparticles, using Nerium oleander leaves extract: Characterization and study of their interaction with organic dyes. Inorg. Chem. Commun. 2019, 105, 36-46. [CrossRef]

24. Boumaza, S.; Yenounne, A.; Hachi, W.; Kaouah, F.; Bouhamidi, Y.; Trari, M. Application of Typha angustifolia (L.) Dead Leaves Waste as Biomaterial for the Removal of Cationic Dye from Aqueous Solution. Int. J. Environ. Res. 2018, 12, 561-573. [CrossRef]

25. Feng, Y.; Liu, Y.; Xue, L.; Sun, H.; Guo, Z.; Zhang, Y.; Yang, L. Carboxylic acid functionalized sesame straw: A sustainable cost-effective bio adsorbent with superior dye adsorption capacity. Bioresour. Technol. 2017, 238, 675-683. [CrossRef] [PubMed]

26. Oliveira, R.N.; Mancini, M.C.; Oliveira, F.C.S.; Passos, T.M.; Quility, B.; Thire, R.M.S.; Mcguiness, G.B. FTIR analysis and quantification of phenols and flavonoids of five commercially available plants extracts used in wound healing. Rev. Matéria 2016, 21,767-779. [CrossRef]

27. Poletto, M.; Zattera, A.J.; Santana, R.M.C. Structural differences between wood species: Evidence from chemical composition, FTIR spectroscopy, and thermogravimetric analysis. J. Appl. Polym. Sci. 2012, 126, 1-8. [CrossRef]

28. Chen, X.; Xu, R.; Xu, Y.; Hu, H.; Pan, S.; Pan, H. Natural adsorbent based on sawdust for removing impurities in waste lubricants. J. Hazard. Mater. 2018, 350, 38-45. [CrossRef]

29. Yang, H.; Yan, R.; Chen, H.; Lee, D.H.; Zheng, C. Characteristics of hemicellulose, cellulose and lignin pyrolysis. Fuel 2007, 86, 1781-1788. [CrossRef]

30. Reddy, K.O.; Maheswari, C.U.; Dhlamini, M.S.; Mothudi, B.M.; Zhang, J.; Zhang, J.; Nagarajan, R.; Rajulu, A.V. Preparation and characterization of regenerated cellulose films using borassus fruit fibers and an ionic liquid. Carbohydr. Polym. 2017, 160, 203-211. [CrossRef]

31. Maaloul, N.; Arfi, R.B.; de la Vega, M.R.; Ghorbal, A.; Díaz, M. Dialysis-free extraction and characterization of cellulose crystals from almond (Prunus dulcis) shells. J. Mater. Environ. Sci. 2017, 8, 4171-4181.

32. Dong, Z.; Hou, X.; Sun, F.; Zhang, L.; Yang, Y. Textile grade long natural cellulose fibers from bark of cotton stalks using steam explosion as a pretreatment. Cellulose 2014, 21, 3851-3860. [CrossRef]

33. Thygesen, A.; Oddershede, J.; Lilholt, H.; Thomsen, A.B.; Stahl, K. On the determination of crystallinity and cellulose content in plant fibres. Cellulose 2005, 12, 563-576. [CrossRef]

34. Kargarzadeh, H.; Ahmad, I.; Abdullah, I.; Dufresne, A.; Zainudin, S.Y.; Sheltami, R.M. Effects of hydrolysis conditions on the morphology, crystallinity, and thermal stability of cellulose nanocrystals extracted from kenaf bast fibers. Cellulose 2012, 19, 855-866. [CrossRef]

35. Trache, D.; Donnot, A.; Khimeche, K.; Benelmir, R.; Brosse, N. Physicochemicalproperties and thermal stability of microcrystalline cellulose isolated from Alfafibres. Carbohydr. Polym. 2014, 104, 223-230. [CrossRef]

36. Bettaieba, F.; Khiari, R.; Hassand, M.L.; Belgacemb, M.N.; Bras, J.; Dufresne, A.; Mhenni, M.F. Preparation and characterization of new cellulose nanocrystals from marine biomass Posidoniaoceanica. Ind. Crop. Prod. 2015, 72, 175-182. [CrossRef]

37. Thambiraj, S.; Shankaran, D.R. Preparation and physicochemicalcharacterization of cellulose nanocrystals from industrial waste cotton. Appl. Surf. Sci. 2017, 412, 405-416. [CrossRef] 
38. Trache, D.; Khimeche, K.; Donnot, A.; Benelmir, R. FTIR spectroscopy and X-raypowder diffraction characterization of microcrystalline cellulose obtainedfrom alfa fibers. MATEC Web Conf. 2013, 3, 1023. [CrossRef]

39. Celekli, A.; Birecikligil, S.S.; Geyik, F.; Bozkurt, H. Prediction of removal efficiency of Lanaset Red G on walnut husk using artificial neural network model. Bioresour. Technol. 2012, 103, 64-70. [CrossRef]

40. Momcilovic, M.; Purenovic, M.; Miljkovic, M.; Bojic, A.; Randjelovic, M. Adsorption of cationic dye methylene blue onto activated carbon obtained from horse chestnut kernel. Hem. Ind. 2011, 65, 123-129. [CrossRef]

41. Wang, Y.; Zhang, X.; He, X.; Zhang, W.; Zhang, X.; Lu, C. In situ synthesis of $\mathrm{mno}_{2}$ coated cellulose nanofibers hybrid for effective removal of methylene blue. Carbohydr. Polym. 2014, 110, 302-308. [CrossRef] [PubMed]

42. Zhou, L.; Huang, J.; He, B.; Zhang, F.; Li, H. Peach gumfor efficient removal of methylene blue and methyl violet dyes from aqueous solution. Carbohydr. Polym. 2014, 101, 574-581. [CrossRef] [PubMed]

43. Mitrogiannis, D.; Markou, G.; Celekli, A.; Bozkurt, H. Biosorption of methylene blue onto Arthrospira platensis biomass: Kinetic, equilibrium and thermodynamic studies. J. Environ. Chem. Eng. 2015, 3, 670-680. [CrossRef]

44. Ai, L.; Li, M.; Li, L. Adsorption of methylene blue from aqueous solution with activated carbon/cobalt ferrite/alginate composite beads: Kinetics, isotherms, and thermodynamics. J. Chem. Eng. Data 2011, 56, 3475-3483. [CrossRef]

45. Zeng, L.; Xie, M.; Zhang, Q.; Kang, Y.; Guo, X.; Xiao, H.; Peng, Y.; Luo, J. Chitosan/organic rectorite composite for the magnetic uptake of methylene blue and methyl orange. Carbohydr. Polym. 2015, 123, 89-98. [CrossRef]

46. Hameed, B.H.; Krishni, R.R.; Sata, S.A. A novel agricultural waste adsorbent for the removal of cationic dye from aqueous solutions. J. Hazard. Mater. 2009, 162, 305-311. [CrossRef]

47. Han, X.; Han, X.; Wang, W.; Ma, X. Adsorption characteristics of methylene blue onto low cost biomass material lotus leaf. Chem. Eng. J. 2011, 171, 1-8. [CrossRef]

48. Belala, Z.; Jeguirim, M.; Belhachemi, M.; Addoun, F.; Trouve, G. Biosorption of basic dye from aqueous solutions by date palm trees: Kinetic, equilibrium and thermodynamic studies. Desalination 2011, 271, 80-87. [CrossRef]

49. Salazar-Rabago, J.J.; Leyva-Ramos, R.; Rivera-Utrilla, J.; Ocampo-Perez, R.; Cerino-Cordova, F.J. Biosorption mechanism of Methylene Blue from aqueous solution onto white pine (Pinus durangensis) sawdust. Effect of operating conditions. Sustain. Environ. Res. 2016, 27, 32-40. [CrossRef]

50. Khodabandehloo, A.; Shayesteh, H.; Rahbar-Kelishami, A. Methylene blue removal using Salix babylonica (Weeping willow) leaves powder as a low-cost biosorbent in batch mode: Kinetic, equilibrium, and thermodynamic studies. J. Mol. Liq. 2017, 244, 540-548. [CrossRef]

51. Sajab, M.S.; Chia, C.H.; Zakaria, S.; Jani, S.M.; Ayob, M.K.; Chee, K.L.; Khiew, P.S.; Chiu, W.S. Citric acid modified kenaf core fibres for removal of methylene blue from aqueous solution. Bioresour. Technol. 2011, 102, 7237-7243. [CrossRef] [PubMed]

52. Abdelkarim, S.; Mohammed, H.; Nouredine, B. Sorption of Methylene Blue Dye from Aqueous Solution Using an Agricultural Waste. Trends Green Chem. 2017, 3, 1-7. [CrossRef]

53. Rubin, E.; Rodriguez, P.; Herrero, R.; Cremades, J.; Barbara, I.; de Vicente, M.E.S. Removal of methylene blue from aqueous solutions using as biosorbent Sargassum muticum: An invasive macroalga in Europe. J. Chem. Technol. Biotechnol. 2005, 80, 291-298. [CrossRef]

54. Hameed, B.H.; El-Khaiary, M.I. Sorption kinetics and isotherm studies of a cationic dye using agricultural waste: Broad bean peels. J. Hazard. Mater. 2008, 154, 639-648. [CrossRef]

55. Vilar, V.J.; Botelho, C.M.; Boaventura, R.A. Methylene blue adsorption by algal biomass based materials: Biosorbents characterization and process behaviour. J. Hazard. Mater. 2007, 147, 120-132. [CrossRef] [PubMed]

56. Nasuha, N.; Hameed, B.H.; Din, A.T. Rejected tea as a potential low-cost adsorbent for the removal of methylene blue. J. Hazard. Mater. 2010, 175, 126-132. [CrossRef]

57. Kumar, K.V.; Kumaran, A. Removal of methylene blue by mango seed kernel powder. Biochem. Eng. J. 2005, 27, 83-93. [CrossRef]

58. Rebitanim, N.Z.; Ghani, W.A.W.A.K.; Mahmoud, D.K.; Rebitanim, N.A.; Salleh, M.A.M. Adsorption capacity of raw empty fruit bunch biomass onto methylene 516 blue dye in aqueous solution. J. Purity Util. React. Environ. 2012, 1, 45-60. 
59. Vadivelan, V.; Kumar, K.V. Equilibrium, kinetics, mechanism, and process design for the sorption of methylene blue onto rice husk. J. Colloid Interface Sci. 2005, 286, 90-100. [CrossRef]

60. Annadurai, G.; Juang, R.-S.; Lee, D.-J. Use of cellulose-based wastes for adsorption of dyes from aqueous solutions. J. Hazard. Mater. 2002, 92, 263-274. [CrossRef]

61. Banerjee, S.; Dastidar, M.G. Use of jute processing wastes for treatment of wastewater contaminated with dye and other organics. Bioresour. Technol. 2005, 96, 1919-1928. [CrossRef]

62. Hameed, B.H.; Ahmad, A.A. Batch adsorption of methylene blue from aqueous solution by garlic peel, an agricultural waste biomass. J. Hazard. Mater. 2009, 164, 870-875. [CrossRef]

63. Banat, F.; Al-Asheh, S.; Al-Makhadmeh, L. Evaluation of the use of raw and activated date pits as potential adsorbents for dye containing waters. Proc. Biochem. 2003, 39, 193-202. [CrossRef]

64. Miyah, Y.; Lahrichi, A.; Idrissi, M.; Khalil, A.; Zerrouq, F. Adsorption of methylene blue dye from aqueous solutions onto walnut shells powder: Equilibrium and kinetic studies. Surf. Interfaces 2018, 11, 74-81. [CrossRef]

65. Mazengarb, S.; Roberts, G.A.F. Studies on the diffusion of direct dyes in chitosan film. Prog. Chem. App. Chitin Derivat. 2009, 14, 25-32.

66. Gucek, A.; Sener, S.; Bilgen, S.; Mazmanci, A. Adsorption and kinetic studies of cationic and anionic dyes on pyrophyllite from aqueous solutions. J. Coll. Interf. Sci. 2005, 286, 53-60. [CrossRef]

67. Ho, Y.S.; McKay, G. The kinetics of sorption of basic dyes from aqueous solution by sphagnum moss peat. Can. J. Chem. Eng. 1998, 76, 822-827. [CrossRef]

68. Ngulube, T.; Gumbo, J.R.; Masindi, V.; Maity, A. Calcined magnesite as an adsorbent for cationic and anionic dyes: Characterization, adsorption parameters, isotherms and kinetics study. Heliyon 2018, 4, 838. [CrossRef]

69. Runping, H.; Pan, H.; Zhaohui, C.; Zhenhui, Z.; Mingsheng, T. Kinetics and isotherms of neutral red adsorption on peanut husk. J. Envrion. Sci. 2008, 20, 1035-1041.

Publisher's Note: MDPI stays neutral with regard to jurisdictional claims in published maps and institutional affiliations.

(C) 2020 by the authors. Licensee MDPI, Basel, Switzerland. This article is an open access article distributed under the terms and conditions of the Creative Commons Attribution (CC BY) license (http://creativecommons.org/licenses/by/4.0/). 